\title{
Interactive effects of vertical mixing, nutrients and ultraviolet radiation: in situ photosynthetic responses of phytoplankton from high mountain lakes in Southern Europe
}

\author{
E. W. Helbling ${ }^{1}$, P. Carrillo ${ }^{2}$, J. M. Medina-Sánchez ${ }^{3}$, C. Durán ${ }^{2}$, G. Herrera ${ }^{2}$, M. Villar-Argaiz ${ }^{3}$, and V. E. Villafañe ${ }^{1}$ \\ ${ }^{1}$ Estación de Fotobiología Playa Unión and Consejo Nacional de Investigaciones Científicas y Técnicas (CONICET) - \\ Casilla de Correos no. 15 (9103) Rawson, Chubut, Argentina \\ ${ }^{2}$ Instituto Universitario de Investigación del Agua, Universidad de Granada, Granada, Spain \\ ${ }^{3}$ Departamento de Ecología, Facultad de Ciencias, Universidad de Granada, Granada, Spain \\ Correspondence to: E. W. Helbling (whelbling@efpu.org.ar)
}

Received: 12 April 2012 - Published in Biogeosciences Discuss.: 31 July 2012

Revised: 16 January 2013 - Accepted: 17 January 2013 - Published: 14 February 2013

\begin{abstract}
Global change, together with human activities, has resulted in increasing amounts of organic material (including nutrients) that water bodies receive. This input further attenuates the penetration of solar radiation, leading to the view that opaque lakes are more "protected" from solar ultraviolet radiation (UVR) than clear ones. Vertical mixing, however, complicates this view as cells are exposed to fluctuating radiation regimes, for which the effects have, in general, been neglected. Furthermore, the combined impacts of mixing, together with those of UVR and nutrient inputs are virtually unknown. In this study, we carried out complex in situ experiments in three high mountain lakes of Spain (Lake Enol in the National Park Picos de Europa, Asturias, and lakes Las Yeguas and La Caldera in the National Park Sierra Nevada, Granada), used as model ecosystems to evaluate the joint impact of these climate change variables. The main goal of this study was to address the question of how short-term pulses of nutrient inputs, together with vertical mixing and increased UVR fluxes modify the photosynthetic responses of phytoplankton. The experimentation consisted in all possible combinations of the following treatments: (a) solar radiation: UVR + PAR (280-700 nm) versus PAR (photosynthetically active radiation) alone $(400-700 \mathrm{~nm})$; (b) nutrient addition (phosphorus $(\mathrm{P})$ and nitrogen $(\mathrm{N})$ ): ambient versus addition (P to reach to a final concentration of $30 \mu \mathrm{g} \mathrm{PL} \mathrm{P}^{-1}$, and $\mathrm{N}$ to reach $\mathrm{N}: \mathrm{P}$ molar ratio of 31 ); and (c) mixing: mixed (one rotation from surface to $3 \mathrm{~m}$ depth (speed of $1 \mathrm{~m} 4 \mathrm{~min}^{-1}$, total of 10 cycles)) versus static. Our findings suggest that un-
\end{abstract}

der ambient nutrient conditions there is a synergistic effect between vertical mixing and UVR, increasing phytoplankton photosynthetic inhibition and excretion of organic carbon (EOC) from opaque lakes as compared to algae that received constant mean irradiance within the epilimnion. The opposite occurs in clear lakes where antagonistic effects were determined, with mixing partially counteracting the negative effects of UVR. Nutrient input, mimicking atmospheric pulses from Saharan dust, reversed this effect and clear lakes became more inhibited during mixing, while opaque lakes benefited from the fluctuating irradiance regime. These climate change related scenarios of nutrient input and increased mixing, would not only affect photosynthesis and production in lakes, but might also further influence the microbial loop and trophic interactions via enhanced EOC under fluctuating UVR exposure.

\section{Introduction}

Increased global temperature, changes in precipitation, enhanced levels of solar ultraviolet radiation (UVR, 280 $400 \mathrm{~nm}$ ) together with other anthropogenic activities (e.g. increasing input of nutrients due to land or agricultural use) have significantly altered natural conditions of aquatic bodies, causing direct and indirect effects on phytoplankton (Hallegraeff, 2010; Häder et al., 2011; United Nations Environment Programme, 2012). Solar UVR, either at normal 
or enhanced levels (due to the depletion of the ozone layer) is generally a stressor for phytoplankton, affecting growth and productivity rates and causing DNA damage, among other effects (see reviews by Buma et al., 2003; Villafañe et al., 2003). However, it can also have positive effects as UV-A energy is used to photorepair DNA damage (Buma et al., 2003) or it can be used for photosynthesis when PAR is limited (Barbieri et al., 2002; Gao et al., 2007). Under conditions of global warming, it is expected that the temperature increase would produce a stronger (i.e. higher gradient at the thermocline) and shallower epilimnion, which may have profound effects on organisms and ecosystems, especially by exposing them to higher radiation levels and/or a different fluctuating radiation field (Häder et al., 2011). Also, under this scenario, nutrients would be depleted from the epilimnion (as mixing with deep waters would be prevented) and thus productivity might decrease (Beardall et al., 2009; Raven et al., 2011); therefore, the impacts of UVR might be greater (Litchman et al., 2002; Shelly et al., 2005). In other cases, however, nutrients would not be limiting, as their inputs occur via the atmosphere or carried by rivers, as shown for various lakes and coastal environments (Xenopoulos et al., 2002; Carrillo et al., 2008; Hessen et al., 2008).

Within any ecosystem different variables can interact in complex synergistic or antagonistic ways (Folt et al., 1999; Crain et al., 2008) and, therefore, exceeding or attenuating the additive effect of single variables. For example, Christensen et al. (2006) showed that changes in biomass of plankton consumers and producers in boreal lakes, over a 23-yr period, were best explained by the interaction between warming, drought, and acidification, rather than by the sum of their individual effects. In another study (Helbling et al., 2003) it was found that the negative effects of UVR on phytoplankton photosynthesis were highly reduced and even reversed under conditions of fast mixing. Carrillo et al. (2008) found that phosphorus (P) inputs from Saharan dust unmasked the deleterious effects of UVR on algae from a high mountain lake. Furthermore, $\mathrm{P}$ inputs increased algal biomass and both, $\mathrm{P}$ inputs and UVR exposure reduced the seston carbon to phosphorus (C:P) ratio (Xenopoulos et al., 2002; Carrillo et al., 2008; Hessen et al., 2008) enhancing consumer growth by simultaneously improving food quantity and quality (VillarArgaiz et al., 2012).

Overall, it is expected that significant interactions between mixing, solar radiation and nutrients would occur and thus it is not possible to predict or extrapolate responses of organisms or ecosystems based on single-variable studies. Moreover, evaluating multifactor interactions influencing ecosystem structure and functioning is critical to the understanding of their response to global change (Crain et al., 2008; Hallegraeff, 2010). This is particularly urgent in southern latitudes of Europe where droughts, atmospheric inputs of nutrients from desert areas or periods of elevated temperature are increasingly frequent events (Bullejos et al., 2010). High mountain lakes have been considered "sentinels of change"
(Williamson et al., 2009), and increasing inputs of terrigenous material (i.e. dissolved organic matter, DOM) have been determined in lakes over a wide range of freshwater environments (Findlay, 2005; Evans et al., 2006). These findings lead to the view that cells in the water column would receive less solar radiation, thus reducing the impact of UVR on the biota of surface waters (Williamson and Rose, 2010). However, previous studies (Villafañe et al., 2004) determined higher rates of UV-B-induced DNA damage in opaque lakes as compared to clear lakes, hinting for the crucial role of vertical mixing by exposing dark-acclimated cells to surface irradiances.

With the aim to assess the effects of multiple variables on phytoplankton photosynthesis we performed experiments in three high mountain lakes of Spain. These lakes have different biological and physical characteristics that allowed for a wide range of responses under relatively similar experimental conditions, so we used them as model ecosystems to respond to a question that now deserves major attention: How does mixing within the epilimnion modify UVR-inhibition of primary producers under inorganic nutrients-pulsed in two contrasting lake scenarios: transparent vs. opaque? Hence, we are testing the following hypothesis: fluctuating irradiance (i.e. due to vertical mixing of the water column), together with nutrient inputs, will cause a greater UVRinduced damage (i.e. assessed through measurements of photosynthetic efficiency and activity) on phytoplankton from opaque lakes as compared to those from clear lakes. This, in turn, would result in higher amounts of carbon released by the UVR-stressed organisms.

\section{Methods}

\subsection{Model ecosystems}

This study was done in three high mountain lakes of Spain (their general characteristics are presented in Table 1): (a) Enol $\left(43^{\circ} 16^{\prime} \mathrm{N}, 4^{\circ} 59^{\prime} \mathrm{W}\right)$ (hereafter LE), located in a calcareous massif at Picos de Europa National Park in the Asturias Province. This lake is oligotrophic (based in its Chl $a$ concentration range), with low light penetration in the water column (Velasco et al., 1999); the lake watershed area is highly influenced by cattle activity; (b) Las Yeguas $\left(37^{\circ} 02^{\prime} \mathrm{N}, 3^{\circ} 22^{\prime} \mathrm{W}\right)$ (hereafter LY), is a small and shallow, with inlets and outlets, and highly transparent oligotrophic lake (Medina-Sánchez et al., 2010) located in Sierra Nevada National Park in the Granada Province; and (c) La Caldera $\left(37^{\circ} 3^{\prime} \mathrm{N}, 3^{\circ} 19^{\prime} \mathrm{W}\right)$ (hereafter LC) is a remote high mountain lake located above the tree-line also in the Sierra Nevada National Park (Granada Province) with no visible inlets or outlets. The lake is oligotrophic, highly transparent (Bullejos et al., 2010) with dissolved organic carbon (DOC) levels generally $<1 \mathrm{mg} \mathrm{L}^{-1}$ (Reche et al., 2001). The pelagic community is strongly P-limited, with DIN to total phosphorus (TP) ratio 
Table 1. General characteristics of the studied lakes and mean concentrations $( \pm \mathrm{SD})$ of inorganic, total and sestonic carbon $(\mathrm{C})$, nitrogen $(\mathrm{N})$ and phosphorus $(\mathrm{P})$ in surface waters of lakes Enol (LE), Las Yeguas (LY) and La Caldera (LC). TP: total phosphorus ( $\mu \mathrm{M})$; SRP: soluble reactive phosphorus $(\mu \mathrm{M})$; TN: total nitrogen $(\mu \mathrm{M})$; $\mathrm{NO}_{3}^{-}$: Nitrate $(\mu \mathrm{M})$; DIN: dissolved inorganic nitrogen $(\mu \mathrm{M})$; DOC: dissolved organic carbon $\left(\mathrm{mgL}^{-1}\right)$. The ratio DIN to TP is expressed by weight.

\begin{tabular}{|c|c|c|c|}
\hline Variable Lake & LE & LY & $\mathrm{LC}$ \\
\hline Height (m a.s.l.) & 1075 & 2800 & 3050 \\
\hline Max. depth (m) & 12 & 8 & 12 \\
\hline Area $\left(\mathrm{m}^{2}\right)$ & 120000 & 2530 & 20000 \\
\hline $\mathrm{TP}$ & $0.110 \pm 0.054$ & $0.109 \pm 0.003$ & $0.128 \pm 0.007$ \\
\hline SRP & $0.075 \pm 0.006$ & $0.051 \pm 0.003$ & $0.047 \pm 0.003$ \\
\hline TN & $26.68 \pm 1.18$ & $11.46 \pm 2.15$ & $12.65 \pm 1.52$ \\
\hline $\mathrm{NO}_{3}^{-}$ & $27.68 \pm 0.28$ & $6.59 \pm 0.23$ & $10.95 \pm 0.91$ \\
\hline DIN & $25.01 \pm 0.44$ & $6.67 \pm 0.2$ & $11.78 \pm 0.53$ \\
\hline DIN/TP & $117.87 \pm 12.53$ & $27.64 \pm 0.27$ & $41.71 \pm 0.4$ \\
\hline DOC & $2.238 \pm 0.45$ & $1.01 \pm 0.11$ & $1.078 \pm 0.08$ \\
\hline $\mathrm{C}: \mathrm{P}$ seston & $513 \pm 123$ & $401 \pm 12$ & $460 \pm 32$ \\
\hline $\mathrm{N}: \mathrm{P}$ seston & $58 \pm 11$ & $30 \pm 1$ & $34 \pm 6$ \\
\hline
\end{tabular}

of 30-90 (by mass) (Carrillo et al., 1996; Villar-Argaiz et al., 2001) and molar algal N:P ratio > 30 (Delgado-Molina et al., 2009). The three lakes are, in general, frozen 7-9 months per year, and they are "open" and accessible only during summer.

The three lakes selected for experimentation share some characteristics that are essential to answer our main question. The three of them receive pulses of nutrient inputs from the surface; however, while in LE these nutrients originate mainly from cattle activity (López-Merino et al., 2011), LY and LC experience frequent inputs of atmospheric Saharan dust containing high $\mathrm{P}$ levels, with $\mathrm{TN}$ to TP ratio ranging from 10 to 50 in dust deposition (Morales-Baquero et al., 2006). Due to this surface input of nutrients, and considering the variables that we are taking into account (i.e. mixing and UVR) our study focused on processes and phytoplankton responses occurring only within the upper part of the water column.

Previous studies (Medina-Sánchez et al., 1999), as well as the data presented here, indicate that none of the lakes develop a deep chlorophyll maxima (DCM) and that phytoplankton is well mixed and equally distributed in the water column. In this study we are not considering deep clear lakes with a DCM (that normally occurs below the epilimnion) as any potential impact of the variables that we are addressing would be indirect on the DCM. In addition, as mentioned before, climate change would drive the water column towards a shallower and more stable epilimnion thus isolating even more the DCM from the upper (stratified) part of the water column.

The experiments carried out in LE were done from 2228 July 2010 whereas those done in LY and LC were done from 10-13 September 2010 (period in which the Saharan dust did not reach the lakes). Before experimentation, the initial physical, chemical, optical and biological characteristics of the water column were determined and water samples were collected for carrying out measurements of photosynthetic activity and efficiency as described below.

\subsection{Experimentation}

To assess the combined effects of vertical mixing, nutrient and ultraviolet radiation (UVR) on carbon incorporation/excretion of natural phytoplankton communities, water samples were taken within the upper $3 \mathrm{~m}$ of the water column and dispensed into round, $50-\mathrm{mL}$ quartz vessels (three clear and one dark per radiation treatment) and incubated with $0.37 \mathrm{MBq}$ of $\mathrm{NaH}^{14} \mathrm{CO}_{3}$ (DHI Water and Environment, Germany) specific activity of $310.8 \mathrm{MBq} \mathrm{mmol}^{-1}$. Two radiation treatments were implemented: (a) PAR + UV-A + UVB (280-700 nm) uncovered vessels (treatment UVR); and (b) only PAR (400-700 nm) (treatment PAR) vessels covered with UV Opak 395 filter (Ultraphan, Digefra) (the spectral characteristics of this filter is published elsewhere; Figueroa et al., 1997). As mentioned before, UV-B and UV-A could have both beneficial and negative impact; however, in our study we did not separate the single effects of each waveband due to space constraints in our in situ incubation system. Nevertheless, the two radiation treatments that we implemented allowed us to determine the overall effects of UVR (i.e. as a balance between the negative and positive effects produced by UV-B and UV-A).

Samples were also exposed to two nutrients conditions: (a) natural (ambient) nutrient concentration (period without nutrient inputs) and, (b) nutrient addition: Phosphorus (as $\mathrm{Na}_{2} \mathrm{HPO}_{4}$ ) to a final concentration of $30 \mu \mathrm{g} \mathrm{PL}{ }^{-1}$, and nitrogen $\left(\right.$ as $\left.\mathrm{NO}_{3} \mathrm{NH}_{4}\right)$ to reach an $\mathrm{N}$ to $\mathrm{P}$ molar ratio of 31 . In this way, we simulated and kept the proportion of nutrient input caused by pulses of Saharan dust as previously shown by Morales-Baquero et al. (2006). It is important to note that we did not pre-acclimate the samples to these enhanced nutrient conditions, as we were interested in assessing any rapid algal response (occurring within a time frame of hours) to the nutrient pulses in combination with mixing and UVR exposure.

The vessels were distributed in two round trays, with one of them put at a fixed depth (static samples - fixed irradiance) that varied between 1.3 and $1.4 \mathrm{~m}$ (according to their PAR attenuation coefficient, $K_{\mathrm{PAR}}$ ) to receive the mean irradiance of the upper $3 \mathrm{~m}$ of the water column (Helbling et al., 1994). The other tray was moved vertically up and down from the surface to $3 \mathrm{~m}$ depth at a constant speed of $1 \mathrm{~m}$ every 4 min (mixed samples - fluctuating irradiance). The depths of incubations were determined both based on temperature profiles obtained in this study and on previous studies conducted in LY and LC (Delgado-Molina, 2008). The number of variables and treatments considered in our study precluded us to carry out in situ static incubations at multiple depths, and thus we used a fixed depth equivalent to the mean PAR irradiance in the upper $3 \mathrm{~m}$ of the water column. This setup 
allowed us to compare among lakes, based on PAR; however, in doing this, and due to the differential attenuation of solar radiation, it was not possible to match both UVR and PAR in the mixing and static treatments, especially in opaque lakes. All this resulted in higher UVR exposure of samples under mixing as compared to static ones, thus, data from lake Enol under mixing might overestimate the impact of UVR as compared to the static samples. The speed of mixing was selected the day before experimentation by doing measurements of the effective photochemical quantum yield (QY) at different depths in the water column and at the surface, and applying the model described in Villafañe et al. (2007). The incubations lasted $4 \mathrm{~h}$ therefore, a total of 10 cycles (surface down to $3 \mathrm{~m}$ - surface) were completed. In the case of LE, we performed an additional experiment by measuring QY under a slower circulation speed of $1 \mathrm{~m}$ every $16 \mathrm{~min}$ (one cycle). The whole setup was deployed from the stern of a small boat that was anchored over a deep section of the lakes, with the stern always facing the Sun. The tray and a UVR-transparent bag (see below) were deployed at about $2 \mathrm{~m}$ away from the side of the boat by using an aluminum pole, so that they did not receive shadows or any type of inputs from the shoreline (this was especially important in LE, as cattle and tourism activities sometimes result in re-suspension of sediments close to shore, thus affecting the underwater light field).

The tray (i.e. mixed samples) was vertically moved in the water column by a custom-made mixing simulator using a frequency-controlled DC motor (Maxon motor, Switzerland) to impose a constant transport rate on the tray. In this moving device, a UVR-transparent bag containing surface lake water $(10 \mathrm{~L})$ was also moved up and down together with, and counterbalancing the previously described tray. The samples inside this bag received full solar radiation, and the water was pumped (in a closed circuit) from the bag to a pulse-amplitude modulated (PAM) fluorometer for measurements of Chl $a$ fluorescence (see below); however, and due to space limitations, no measurements were performed under other different radiation treatments. A custom-made darkened flow-through measuring quartz cuvette $(5 \mathrm{~mL})$ was connected to a pump that continuously pumped water containing phytoplankton from and to the bag via a dark $4 \mathrm{~m}$ silicon tube ( $5 \mathrm{~mm}$ diameter). The flow rate was ca. $250 \mathrm{~mL} \mathrm{~min}^{-1}$, so it was enough to keep cells a minimum of time $(<1 \mathrm{~min})$ in the silicon tube before being measured. Fluorescence of Chl $a$ data was acquired at a frequency of 1 datum every $10 \mathrm{~s}$ during $2 \mathrm{~h}$ of incubation.

\subsection{Analyses and measurements}

The following measurements and analyses were done during these experiments:

Solar radiation: incident solar radiation was continuously monitored using a surface BIC compact 4-channel radiometer (Biospherical Instruments Inc., CA, USA) that has three channels in the UVR region $(305,320$, and $380 \mathrm{~nm})$ and one broadband channel for PAR (400-700 nm). Vertical profiles of solar radiation in the water column were also obtained at noon with a submersible BIC compact 4-channel radiometer (Biospherical Instruments Inc., CA, USA) that has the same channels as described before, in addition to temperature and depth sensors. The mean PAR irradiance within the upper $3 \mathrm{~m}$ of the water column ( $\mathrm{I}_{\mathrm{m}(\mathrm{PAR})}$ was calculated as

$I_{\mathrm{m}(\mathrm{PAR})}=I_{0(\mathrm{PAR})}\left[1-\exp \left(-k_{\mathrm{d}(\mathrm{PAR})} z\right)\right] / k_{\mathrm{d}(\mathrm{PAR})} z$,

where $\mathrm{I}_{0(\mathrm{PAR})}$ is the mean incident surface irradiance, $k_{\mathrm{d}(\mathrm{PAR})}$ is the mean attenuation coefficient for PAR, and $z$ is the depth to where the samples were mixed $(3 \mathrm{~m})$. In the case of fixed samples the mean PAR irradiance, comparable to a $3 \mathrm{~m}$ mixing layer, was received at 1.3 or $1.4 \mathrm{~m}$ depth. The mean attenuation coefficient of PAR for the water column was calculated from the irradiance vs. depth profiles done with the submersible radiometer, fitting all the data points $(n>200$ per profile) with an exponential curve.

Physical and chemical characteristics of the water column: temperature, conductivity, dissolved oxygen, and $\mathrm{pH}$ were determined using a multiparameter probe (Turo water quality analysis T-611). Vertical profiles of these variables were obtained daily at noon; temperature data was used to determine the strength of the thermocline and the depth of the epilimnion in the water column.

The total $\mathrm{CO}_{2}$ concentration in the lakes was calculated from alkalinity and $\mathrm{pH}$ measurements (APHA, 1992). Spectrophotometric techniques were used to determine nitrate $\left(\mathrm{NO}_{3}^{-}\right)$and soluble reactive P (SRP) (APHA, 1992). Samples for total phosphorus (TP) and total nitrogen (TN) were digested using potassium persulfate at $120^{\circ} \mathrm{C}$ for $30 \mathrm{~min}$, and then analyzed as SRP or $\mathrm{NO}_{3}^{-}$, respectively (APHA, 1992). Seston samples were collected in triplicate by filtering 300-500 $\mathrm{mL}$ onto pre-combusted filters (Whatman GF/F $25 \mathrm{~mm}$ diameter). The samples were analyzed for $\mathrm{C}$ and $\mathrm{N}$ using a CNH analyser (Perkin-Elmer Model 2400), and for $\mathrm{P}$ content by a colorimetric method after persulphate oxidation (APHA, 1992). The C:N:P ratios were calculated on molar basis.

Incorporated and excreted carbon: after the $4 \mathrm{~h}$ of in situ exposure to solar radiation, the samples were immediately filtered under low pressure $(<100 \mathrm{mmHg})$ to minimize cell breakage, and fractionated in size fractions as follows: samples from LE were filtered through $3 \mu \mathrm{m}$ Whatman GF/D filters $(25 \mathrm{~mm}$ diameter) and then through $0.7 \mu \mathrm{m}$ Whatman $\mathrm{GF} / \mathrm{F}$ filters $(25 \mathrm{~mm}$ diameter) to determine the presence of picoautotrophs $(3-0.7 \mu \mathrm{m})$ that might have incorporated some carbon. However, samples from LC and LY were filtered only through $1 \mu \mathrm{m}$ Nuclepore filters ( $25 \mathrm{~mm}$ diameter) as previous studies (Carrillo et al., 2002) already confirmed the absence of picoautotrophs. The filters were put in 20$\mathrm{mL}$ scintillation vials, and inorganic carbon was removed by adding $100 \mu \mathrm{L}$ of $1 \mathrm{~N} \mathrm{HCl}$ and allowing the vial to stand open in a hood for $24 \mathrm{~h}$ (no bubbling) (Lignell, 1992). Excreted organic carbon (EOC) was measured in $4 \mathrm{~mL}$ subsamples, 
collected from the 0.7 or $1 \mu \mathrm{m}$ filtrate that were put in $20-\mathrm{mL}$ scintillation vials, together with $100 \mu \mathrm{L}$ of $1 \mathrm{~N} \mathrm{HCl}$ to eliminate the excess inorganic radiocarbon. After acidification, scintillation cocktail (Ecoscint A) was added to both samples for carbon incorporation and excretion, and counted using a scintillation counter (Beckman LS 6000TA) equipped with an internal calibration source. The carbon incorporated and excreted was calculated based on the CPMs, and in all calculations the dark values were subtracted from the light values. The $\%$ EOC was calculated as

$\% \mathrm{EOC}=\mathrm{EOC} /(\mathrm{EOC}+\mathrm{POC}) \times 100$.

Chl a fluorescence parameters: $\mathrm{Chl} a$ fluorescence parameters were obtained using a pulse amplitude modulated fluorometer (Water PAM, Walz, Germany). Because the time between sampling and fluorescence measurements were in the order of a few seconds, the intrinsic photochemical efficiency of PSII (photosystem II) (QY) in the light was determined (Maxwell and Johnson, 2000). These fluorescence measurements were done every $10 \mathrm{~s}$ during the vertical movement of the samples. The measurements were not affected by pumping phytoplankton from and to the cuvette as previously determined by comparing pumped versus water taken directly with a syringe.

Chl a concentration: at the beginning of each experiment aliquots of $250-1000 \mathrm{~mL}$ of sample were filtered onto Whatman $\mathrm{GF} / \mathrm{F}$ filters $(25 \mathrm{~mm}$ diameter); the filters were then frozen at $-20^{\circ} \mathrm{C}$ until analyses. Once in the laboratory, samples were thawed and put in centrifuge tubes $(15 \mathrm{~mL})$ with $5 \mathrm{~mL}$ of absolute methanol (Holm-Hansen and Riemann, 1978). The tubes containing the methanolic extract and filters were put in a sonicator for $20 \mathrm{~min}$ and then in the dark $\left(4{ }^{\circ} \mathrm{C}\right)$ for at least $1 \mathrm{~h}$. After the extraction period the sample was centrifuged $(15 \mathrm{~min}$ at $1750 \mathrm{~g})$ and scanned (250$750 \mathrm{~nm}$ ) in a UV-VIS spectrophotometer (Lambda 40 Perkin Elmer, USA) using a 5-cm path-length cuvette; Chl $a$ concentration was calculated using the equation of Porra (2002). The same sample was also used to calculate $\mathrm{Chl} a$ concentration from the fluorescence of the extract (Holm-Hansen et al., 1965) before and after acidification (1N HCl) using a spectrofluorometer (LS 55 Perkin Elmer, USA). There were no significant differences between the Chl $a$ concentrations obtained by these two methods so we used the fluorometric measurements in all calculations.

Taxonomic analyses: samples for identification and enumeration of phytoplankton were put in $250-\mathrm{mL}$ brown glass bottles and fixed with Lugol's reagent $\left(1 \% \mathrm{vol} \mathrm{vol}^{-1}\right)$. A variable amount of sample $(50-100 \mathrm{~mL})$ was allowed to settle for $48 \mathrm{~h}$ in Utermöhl chambers (Hydro-Bios GmbH, Germany) and species were enumerated and identified using an inverted microscope (Leitz Fluovert FS, Leica, Wetzlar, Germany) following the technique described by Villafañe and Reid (1995). Phytoplankton biovolumes were estimated from measurements of 20-30 cells of each species using image analysis (Inverted microscope Axio Observer
A1, Zeiss - High resolution microscopy camera Axiocam HRc, Zeiss); biovolumes were calculated according to Carrillo et al. (1995). Cell volume was converted to phytoplankton carbon using the conversion factors reported by Rocha and Duncan (1985).

\subsection{Data treatment, calculations and statistics}

The data are reported as mean and standard deviation. The inhibition of photosynthesis due to UVR $\left(\mathrm{UVR}_{\mathrm{inh}}\right)$ was calculated as

$\mathrm{UVR}_{\mathrm{inh}}(\%)=100\left[\left(\mathrm{C}_{\mathrm{PAR}}-\mathrm{C}_{\mathrm{UVR}}\right)\right] / \mathrm{C}_{\mathrm{PAR}}$,

where $\mathrm{C}_{\mathrm{PAR}}$, and $\mathrm{C}_{\mathrm{UVR}}$ represent the carbon fixed in samples under the PAR only, and PAR + UV-A + UV-B treatments, respectively. We used propagation errors to calculate the variance of percentage inhibition due to UVR.

To determine significant interactions among the three factors - radiation treatment, nutrients addition and mixing regime, we used a three-way ANOVA (analysis of variance) test. When significant differences were determined, a post hoc Fisher LSD (least significant difference) test was used to determine significant differences among and within the different factors.

The points presented in Fig. 7 were based on our own results as well as on previous published studies to extend the relationship obtained in our studied lakes. The calculations for obtaining these additional points were as follows:

Point 1 (Köhler et al., 2001): the authors made a comparison between rotating (26\% inhibition) and static (32\% inhibition) treatments (this latter based on a previous work of their own). Thus, point 1 was calculated using a $-6 \%$ inhibition value (i.e. $26 \%$ (mixed) $-32 \%$ (static)), and normalizing it by a mean PAR of $692 \mu \mathrm{E} \mathrm{m}^{-2} \mathrm{~s}^{-1}\left(148.5 \mathrm{~W} \mathrm{~m}^{-2}\right)$ as stated in their Table 1 for the $0-3.9 \mathrm{~m}$ depth mixing. The authors used $k_{320}$ of $1.3 \mathrm{~m}^{-1}$.

Point 2 (Hiriart-Baer and Smith, 2005): we used their predictions based on data previously collected by the authors, and we calculated an inhibition difference between mixing and static conditions ca. $8 \%$. In this study, the PAR value was not given, but the authors mentioned values of 6.9 and $9.6 \%$ of mean PAR for the West Basin. The authors also quoted their previous work (Hiriart-Baer and Smith, 2004) where maximum values of incident PAR were given for various days, mean ca. $160 \mathrm{~W} \mathrm{~m}^{-2}$; thus, the mean irradiance that we used for our calculations was $13 \mathrm{~W} \mathrm{~m}^{-2}$. Hiriart-Baer and Smith (2005) also stated a $k_{320}$ of $2.8 \mathrm{~m}^{-1}$ for the West Basin.

Point 3 (Villafañe et al., 2007): for the calculations we used the mixed condition, which was established as having the water column well mixed down to $3 \mathrm{~m}$ depth. Under this condition, the mean UVR inhibition in the static sample during the morning was $46.7 \%$. The estimation of the inhibition in the mixing condition was obtained as follows: there was a decrease in yield (during the period of intense mixing) 
from the initial value in the morning to that at noon, with a mean water column inhibition for this period of $43.5 \%$. This inhibition was caused by both, UVR and PAR acting together. Since the authors did not separate the effects of UVR and PAR, we used a conservative value of $40 \%$ inhibition due to PAR, based on the results of their static incubation. Static samples were incubated at the surface of the lake and received a mean morning $(8-12 \mathrm{~h})$ value ca. $150 \mathrm{~W} \mathrm{~m}^{-2}$ whereas the mixed samples received much less (mean ca. $40 \mathrm{~W} \mathrm{~m}^{-2}$ ) as they were mixing down to $3 \mathrm{~m}$ depth. The authors stated an attenuation coefficient for UV-B of $2.96 \mathrm{~m}^{-1}$.

\section{Results}

The initial conditions (i.e. just before experimentation) of inorganic, total and seston carbon $(\mathrm{C})$, nitrogen $(\mathrm{N})$ and phosphorus $(\mathrm{P})$ in surface waters are presented in Table 1. This initial condition (treatment without nutrients) was obtained during a period without Saharan dust input, therefore nutrients in the water column were low as compared with our treatment with an extra input of nutrients (that simulated Pinput associated with Saharan dust or increasing cattle activity as is the case of Lake Enol). The most evident feature in these initial conditions was the higher nitrate and DIN concentration (and TN) in LE as compared to LC and LY, further reflected in the DIN to TP ratio that was 3-4 times higher in the former. Also, the DOC concentration in LE doubled that of LC and LY. Other chemical variables, e.g. TP and SRP were rather similar among the lakes.

Incident solar radiation conditions were, in general, of clear skies over LY and LC, while high variability due to cloud cover predominated over LE (data not shown). The mean surface PAR irradiances during the incubation periods were $1558(\mathrm{SD}=271), 1670$ and $1774(\mathrm{SD}=14) \mu \mathrm{mol}$ photons $\mathrm{m}^{-2} \mathrm{~s}^{-1}$ for $\mathrm{LE}, \mathrm{LY}$ and $\mathrm{LC}$, respectively. In regard to the underwater radiation field, profiles (Fig. 1) indicated that LE was the darkest, followed by LY whereas LC was the most transparent (e.g. $k_{320}$ of $2.28,0.58$, and $0.26 \mathrm{~m}^{-1}$ (Fig. 1b), and $K_{\mathrm{PAR}}$ of $0.34,0.18$, and $0.16 \mathrm{~m}^{-1}$, respectively (Fig. 1d)).

Temperature profiles (Fig. 2a) showed different stratification conditions in the lakes: LE had the highest surface temperatures $\left(20^{\circ} \mathrm{C}\right)$ and a marked epilimnion down to ca. $3 \mathrm{~m}$ depth (stratified condition) below which temperature decreased continuously to reach $9{ }^{\circ} \mathrm{C}$ at $12 \mathrm{~m}$. In LC a weak stratification was observed, with surface temperature of $14^{\circ} \mathrm{C}$ and decreasing to $\sim 12{ }^{\circ} \mathrm{C}$ at $1 \mathrm{~m}$ depth; below it the temperature remained constant. LY was well mixed, having a nearly constant temperature $\left(\sim 14.5^{\circ} \mathrm{C}\right)$ from surface to bottom. The $\mathrm{Chl} a$ concentration in the water column increased with depth in LE, but remained rather constant in LY and LC (Fig. 2b); the mean Chl $a$ concentrations at surface waters were $2.1,1.1$ and $0.7 \mu \mathrm{g} \mathrm{Chl} a \mathrm{~L}^{-1}$ in LE, LY and LC, respectively. The concentration of phytoplankton cells
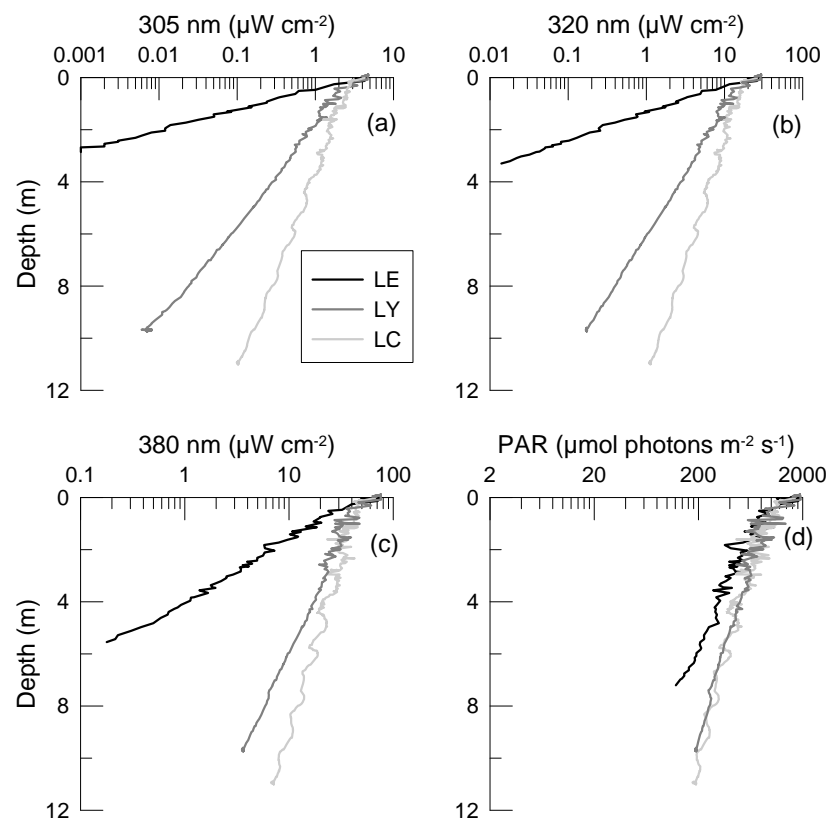

Fig. 1. Solar irradiance as a function of depth in lakes Enol (LE), Las Yeguas (LY) and La Caldera (LC): (a) $305 \mathrm{~nm}$; (b) $320 \mathrm{~nm}$; (c) $380 \mathrm{~nm}$ and, (d) PAR (400-700 nm). Irradiance data in the UVR range are expressed in $\mu \mathrm{W} \mathrm{cm}{ }^{-2}$, PAR is in $\mu$ mol photons $\mathrm{m}^{-2} \mathrm{~s}^{-1}$.

(Fig. 2c) was higher in LE $\left(\sim 3600\right.$ cells $\mathrm{mL}^{-1}$ in surface waters) as compared to the other two lakes that had similar abundances ( $\sim 2000$ cells $\mathrm{mL}^{-1}$ in surface waters) and depth distributions. Phytoplankton biomass, expressed as carbon concentration (Fig. 2d) had high values at the surface in LY $\left(51 \mu \mathrm{g} \mathrm{CL}^{-1}\right)$, followed by $\mathrm{LE}\left(33 \mu \mathrm{g} \mathrm{C} \mathrm{L}{ }^{-1}\right)$ and low values $\left(6.1 \mu \mathrm{g} \mathrm{C} \mathrm{L}{ }^{-1}\right)$ in LC.

Taxonomic analyses (Table 2) revealed important differences among the lakes, with Chlorophyceae dominating (in terms of abundance) in LE (e.g. Dictyosphaerium chlorelloides (Nauman) Komárek and Perman), Bacillariophyceae in LY (e.g. Cyclotella minuta (Skvortzov) Antipova), and Chrysophyceae (e.g. Chromulina nevadensis P. M. Sánchez) in LC. However, when considering the share of carbon to the total community, Bacillariophyceae dominated in LE and LY (67 and $87 \%$, respectively) whereas in LC Chrysophyceae contributed for the bulk of the biomass (68\%). By comparing both the abundance and biomass of each taxonomic class (Table 2) it is obvious there are differences in cell size and carbon content per cell among the lakes; for example, in LE diatoms had a mean carbon content of $24 \mathrm{pgC}$ cell $^{-1}$ but in LY they were larger, with $38 \mathrm{pgC}$ cell $^{-1}$.

In the three lakes, there were no significant differences $(P>0.05, n>700)$ in the photochemical efficiency of PSII (QY) in the upper $3 \mathrm{~m}$ of the water column, so the mean values are presented in Fig. 3a. In LE there were significant differences in QY $(P<0.05, n=700)$ among experiments carried out during cloudy and sunny conditions under 
Table 2. Surface phytoplankton composition and abundance (in cells $\mathrm{mL}^{-1}$ ), and phytoplankton biomass content (in $\mu \mathrm{g} \mathrm{C} \mathrm{L}^{-1}$ ) in lakes Enol (LE), Las Yeguas (LY) and La Caldera (LC).

\begin{tabular}{l|rrrrrr}
\hline \multirow{2}{*}{ Family } & \multicolumn{2}{|c}{ LE } & \multicolumn{2}{c}{ LY } & LC \\
\cline { 2 - 7 } & Abundance & Biomass & Abundance & Biomass & Abundance & Biomass \\
\hline Chlorophyceae & 2270 & 6.06 & 676 & 4.13 & 382 & 1.03 \\
Cryptophyceae & 211 & 3.62 & 94 & 1.34 & 29 & 0.33 \\
Chrysophyceae & 64 & 0.91 & 113 & 1.03 & 1559 & 4.22 \\
Desmidiaceae & 9 & 0.15 & & & & \\
Bacillariophyceae & 916 & 22.11 & 1176 & 44.89 & 2 & 0.05 \\
Dinophyceae & 129 & 0.13 & 4 & 0.14 & 28 & 0.51 \\
\hline TOTAL & 3599 & 32.98 & 2063 & 51.73 & 2000 & 6.14 \\
\hline
\end{tabular}
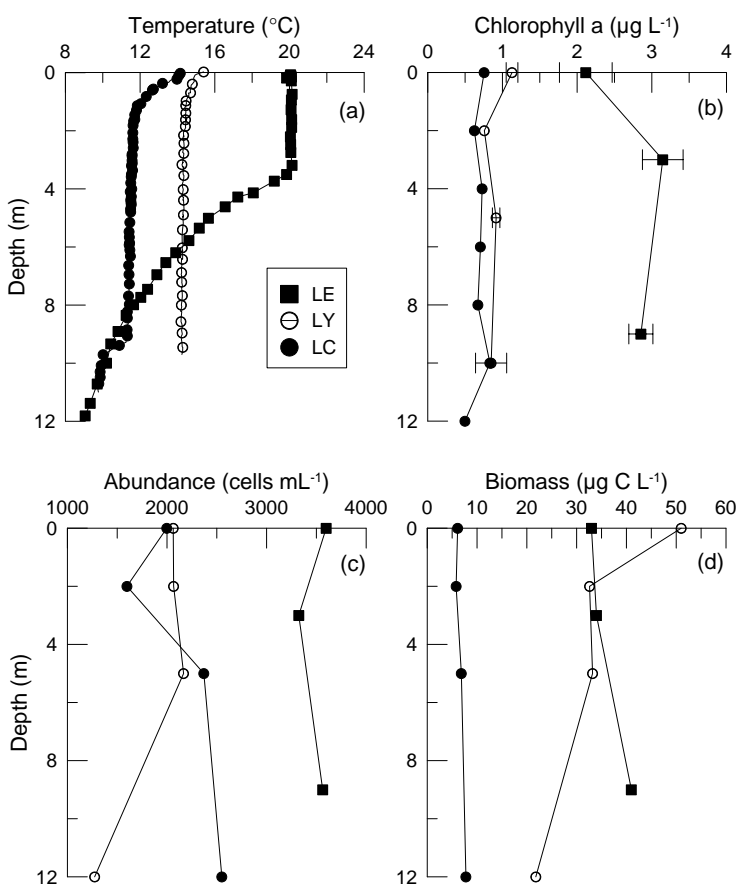

Fig. 2. Water column structure and phytoplankton distribution as a function of depth in lakes Enol (LE), Las Yeguas (LY) and La Caldera (LC). (a) Temperature (in ${ }^{\circ} \mathrm{C}$ ); (b) Chlorophyll $a$ (in $\mu \mathrm{g} \mathrm{L}^{-1}$ ); (c) Phytoplankton abundance (in cells $\mathrm{mL}^{-1}$ ); and (d) Phytoplankton biomass (in $\mu \mathrm{g} \mathrm{CL}^{-1}$ ).

the same mixing regime (Fig. 3a). There was also a significant difference in QY during sunny conditions when samples were subjected to the two mixing regimes, so that at a fast mixing speed (i.e. $1 \mathrm{~m} 4 \mathrm{~min}^{-1}$ ) QY was significantly lower $(P<0.05, n>250)$ than at a speed of $1 \mathrm{~m}^{16 \mathrm{~min}^{-1}}$ (Fig. 3a). Moreover, and at the speed of $1 \mathrm{~m}^{4} \mathrm{~min}^{-1}$, QY at LY was significantly higher $(P<0.05)$ than at the other two lakes, but there were no significant differences $(P>0.05)$ in QY when comparing with LE samples moving at $1 \mathrm{~m} 6 \mathrm{~min}^{-1}$. The mean irradiance conditions in the upper
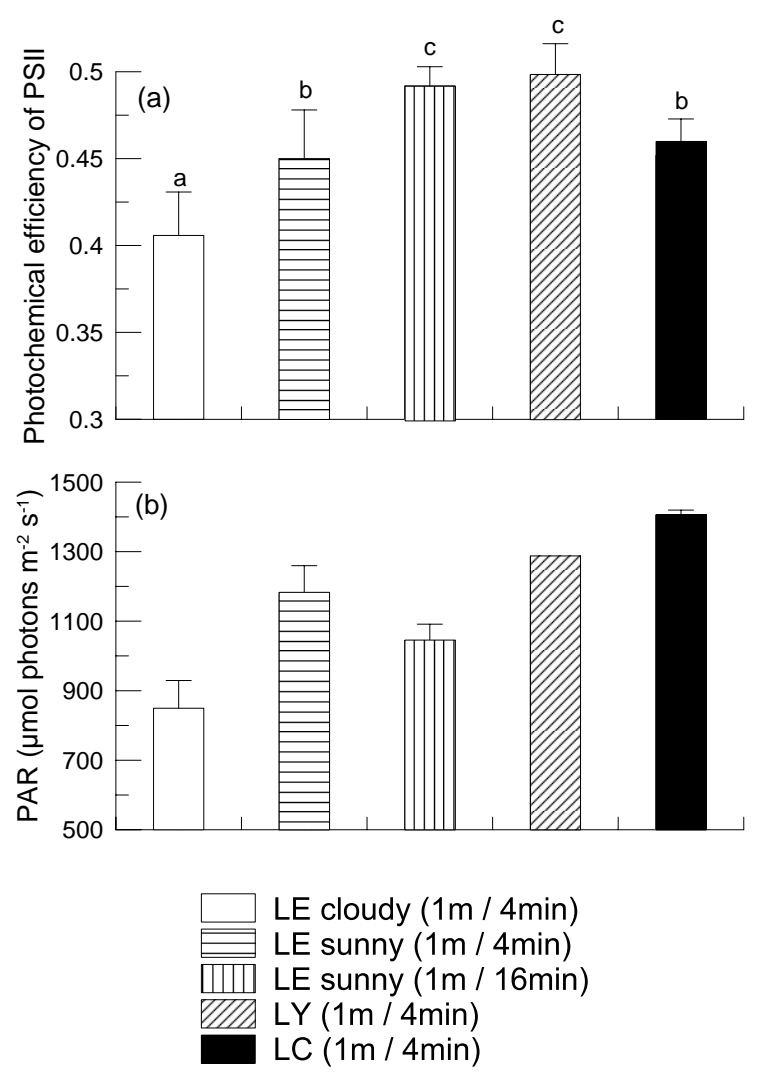

Fig. 3. (a) In situ effective photochemical quantum yield (QY) and, (b) mean PAR irradiance (in $\mu \mathrm{mol}$ photons $\mathrm{m}^{-2} \mathrm{~s}^{-1}$ ) in the upper $3 \mathrm{~m}$ of the water column during measurements carried out in lakes Enol (LE) (cloudy and sunny days, under different mixing speeds), Las Yeguas (LY) and La Caldera (LC). The lines on top of the bars are the standard deviation whereas the letters indicate differences among conditions.

$3 \mathrm{~m}$ of the water column are shown in Fig. 3b: LY and LC received relatively higher PAR levels than LE due to a combination of high surface incident irradiances during cloudless days, and $K_{\mathrm{PAR}}$ values that were half of that in LE (i.e. 0.16 
vs. $0.34 \mathrm{~m}^{-1}$ ). The lowest mean PAR irradiance in the upper $3 \mathrm{~m}$ of the water column was determined in LE under cloudy conditions.

The rate of phytoplankton carbon fixation was highly variable not only among the lakes, but it also depended on the experimental conditions imposed to the samples (Fig. 4). In LE (Fig. 4a) there were no significant differences between radiation treatments or nutrient addition in the $>3 \mu \mathrm{m}$ fraction under the mixing condition, but in the $3-0.7 \mu \mathrm{m}$ fraction samples receiving UVR had significant lower carbon fixation than those exposed only to PAR. The carbon fixed in the $>3 \mu \mathrm{m}$ fraction was significantly higher $(P<0.05)$ than in the $3-0.7 \mu \mathrm{m}$ fraction, with the exception of both UVR treatments in static conditions. In LY (Fig. 4b) significant interactive effects between the three studied factors were determined (Table A1 in Supplement). All samples exposed to UVR had significantly lower carbon fixation than those exposed only to PAR. In addition, two of the samples in the mixing regime (treatments UVR and PAR $+\mathrm{P}$ ) had significant higher carbon fixation as compared to the static ones. Also, and under mixing conditions, samples with an addition of nutrients had higher carbon fixation than those without it for the same radiation treatment. In static samples, nutrient addition increased carbon fixation under UVR but not in samples receiving only PAR. Finally, in LC (Fig. 4c) there were interactive effects between mixing regime, radiation treatments and nutrient addition (Table A1 in Supplement). Carbon fixation in the samples with added nutrients was significantly higher than those without it, in both static and mixing regimes. Also, nutrient addition "highlighted" the UVR effects under mixing conditions, with significantly higher carbon fixation in the PAR $+\mathrm{P}$ as compared to UVR $+\mathrm{P}$ treatments, but there were no significant effects of UVR when nutrients were not added. In static samples, UVR had significant effects regardless the nutrient treatment.

Using the carbon incorporation data (Fig. 4) we calculated the UVR-induced inhibition for each lake and condition (Fig. 5). The UVR-induced inhibition of carbon fixation in LE (Fig. 5a) was ca. $20 \%$ under mixing in the 3$0.7 \mu \mathrm{m}$ fraction, whereas under static conditions negative inhibition values were obtained due to a decrease in carbon fixation in samples exposed to PAR (as seen in Fig. 4a). The effects of UVR and nutrients were especially evident in the $>3 \mu \mathrm{m}$ fraction under static conditions, with negative inhibition $(-20 \%)$ in samples without nutrient addition, whereas it reached $48 \%$ in those that received them, due to a significant increase in carbon fixation in the $\mathrm{PAR}+\mathrm{P}$ treatment (as seen in Fig. 4a). In LY (Fig. 5b) significant inhibition was determined in all treatments (60-80\%) but samples with nutrient addition and under static conditions were those having the lowest values, i.e. $34 \%$. Finally, UVR-induced inhibition in phytoplankton from LC ranged from 30 to $90 \%$ in samples without nutrient addition under mixing and static conditions, respectively (Fig. 5c).
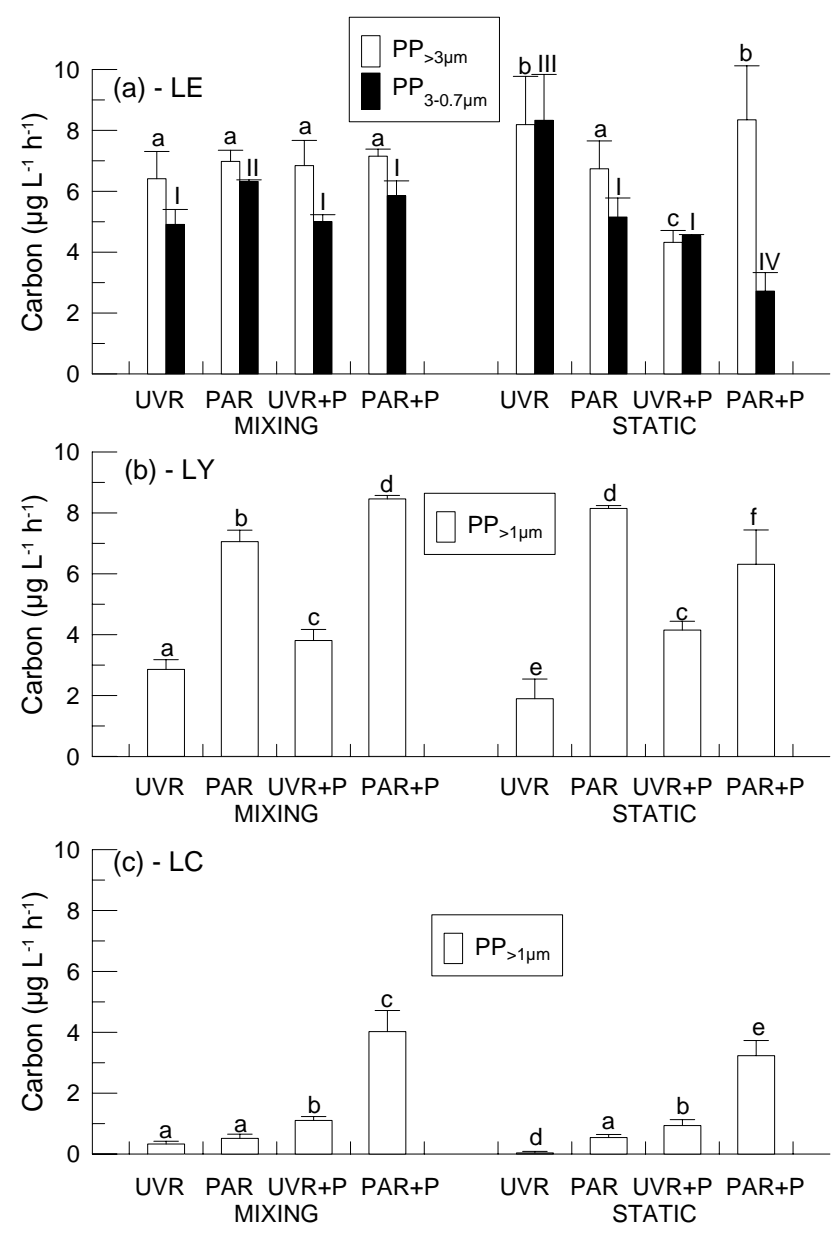

Fig. 4. Rates of carbon incorporation (in $\mu \mathrm{g} \mathrm{CL}^{-1} \mathrm{~h}^{-1}$ ) under different radiation (UVR versus PAR alone), phosphorus concentration (ambient versus $30 \mu \mathrm{P} \mathrm{L}^{-1}$ ) and mixing regime (mixing versus static) conditions in: (a) Lake Enol (LE): $>3 \mu \mathrm{m}$ fraction (white bars), 3-0.7 $\mu \mathrm{m}$ fraction (black bars); (b) Lake Las Yeguas (LY); and (c) Lake La Caldera (LC). The lines on top of the bars are the standard deviation whereas the letters and numbers indicate differences among treatments.

The excreted organic carbon (EOC) was significantly higher in LE as compared to the other lakes (Fig. 6). There were significant interactions between mixing regimes, radiation treatments and nutrient addition (Table A2 in Supplement). In particular, for LE (Fig. 6a) the amount and percentage of EOC in the PAR-only exposed samples during the mixing regime were similar to those that additionally received UVR. In the static conditions, the addition of nutrients resulted in less EOC in samples exposed to UVR as compared to the samples in which no nutrients were added. In LY (Fig. 6b), samples under mixing conditions had equal or significantly lower amounts of EOC than similar treatments in the static ones, while in LC (Fig. 6c) the opposite occurred, particularly in samples receiving nutrients. In general, the addition of nutrients resulted in significant less amount of EOC 

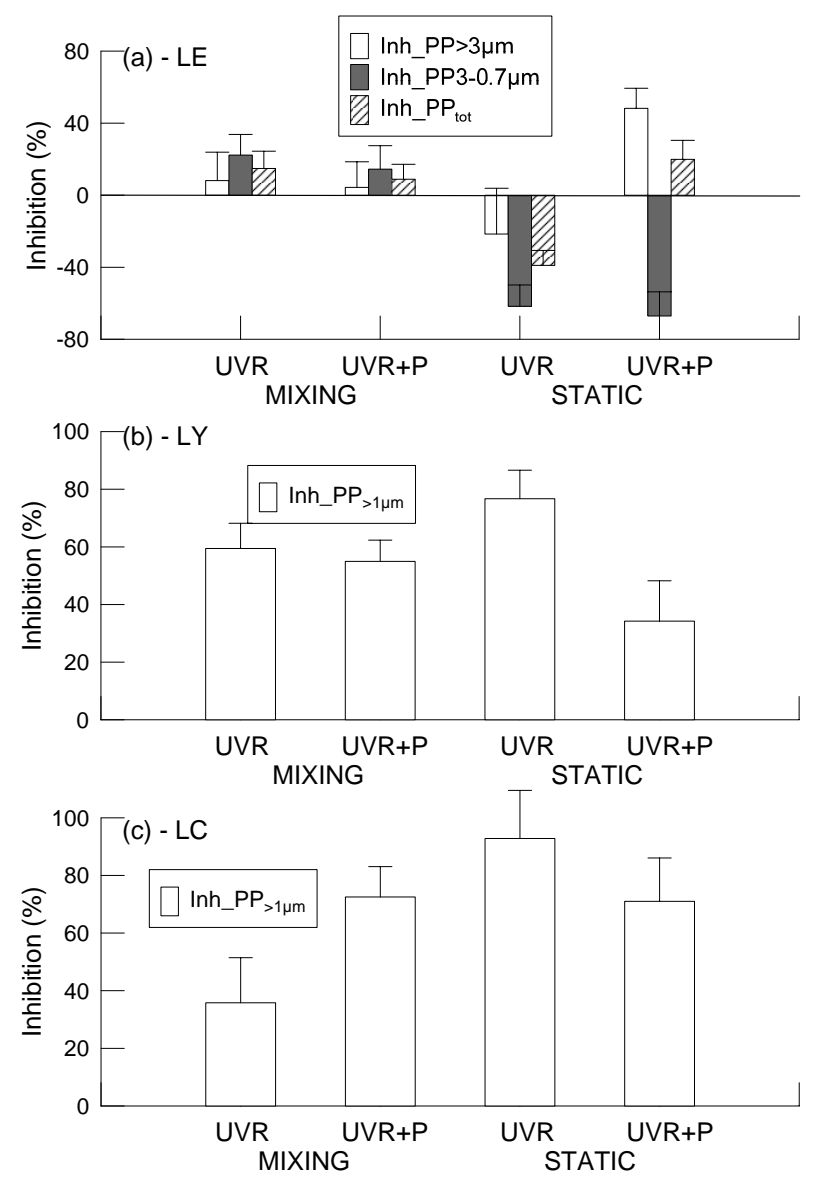

Fig. 5. Percentage inhibition of carbon fixation (\%) due to UVR under different phosphorus concentration (ambient versus $30 \mu \mathrm{g} \mathrm{PL}^{-1}$ ) and mixing regime (mixing versus static) conditions in: (a) Lake Enol (LE): > $3 \mu \mathrm{m}$ fraction (white bars), 3-0.7 $\mu \mathrm{m}$ fraction (gray bars), total (hatched bars); (b) Lake Las Yeguas (LY); and (c) Lake La Caldera (LC). The lines on top of the bars are the standard deviation.

in LY and LC under static conditions (Fig. 6b, c). In regard to the percentage of EOC, the general pattern was of higher values in LC $(>50 \%)$, followed by LY $(>35 \%)$ and then $\operatorname{LE}(>20 \%)$.

In order to relate the results obtained in the three lakes we plotted the UVR-induced inhibition of carbon fixation as the difference between mixed and static conditions (Fig. 7). Since the experimentation in the three lakes was conducted on different dates, we normalized the inhibition values by the amount of solar radiation received by the cells. These values were plotted as a function of the attenuation coefficient for UV-B $\left(k_{320}\right)$, considering independently the treatments with (three open circles in Fig. 7) or without nutrient addition (three black squares in Fig. 7). There was a significant trend (gray thick line) in these data, with the inhibition difference decreasing towards lower $k_{320}$ values. Since the logistics involved to conduct in situ mixing experiments precluded us
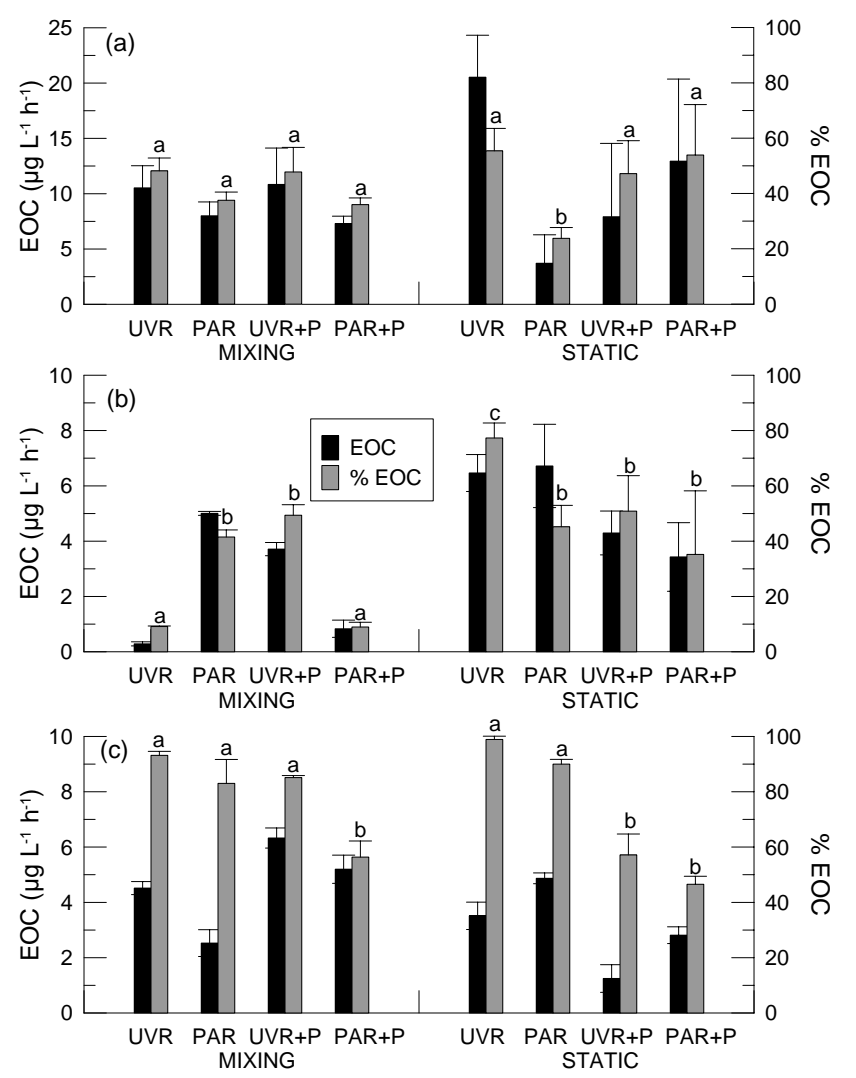

Fig. 6. Concentration of excreted organic carbon (EOC, in $\mu \mathrm{g} \mathrm{CL}^{-1} \mathrm{~h}^{-1}$ - black bars) and percentage EOC (in \% - gray bars) under different radiation (UVR versus PAR alone), phosphorus concentration (ambient versus $30 \mu \mathrm{g} \mathrm{PL}^{-1}$ ) and mixing regime (mixing versus static) conditions in: (a) Lake Enol (LE); (b) Lake Las Yeguas (LY); and (c) Lake La Caldera (LC). The lines on top of the bars are the standard deviation whereas the letters indicate differences among treatments.

to repeat the experiments in more lakes under similar conditions, we expanded this relationship by having more data points derived from some of the few studies conducted in other lakes where mixing experiments (or models obtained based on them) were conducted. We used three published studies (Köhler et al., 2001; Hiriart-Baer and Smith, 2005; Villafañe et al., 2007) to derive the data points 1, 2 and 3, respectively, used in Fig. 7 (black circles), as explained in the Methods Sect. In spite of the variability in responses observed between the different studies, a significant trend for the difference in inhibition of carbon fixation in mixed and static samples without addition of nutrients was observed (black thin line, Fig. 7). In opaque lakes (i.e. with high $k_{320}$ ) the inhibition was higher under mixed than under static conditions, and it decreased towards clear lakes with negative values, indicating that inhibition was higher in the static conditions, and that mixing counteracted the negative effects of UVR. An interesting result is that the addition of nutrients seemed to reverse the pattern, with mixing either enhancing 


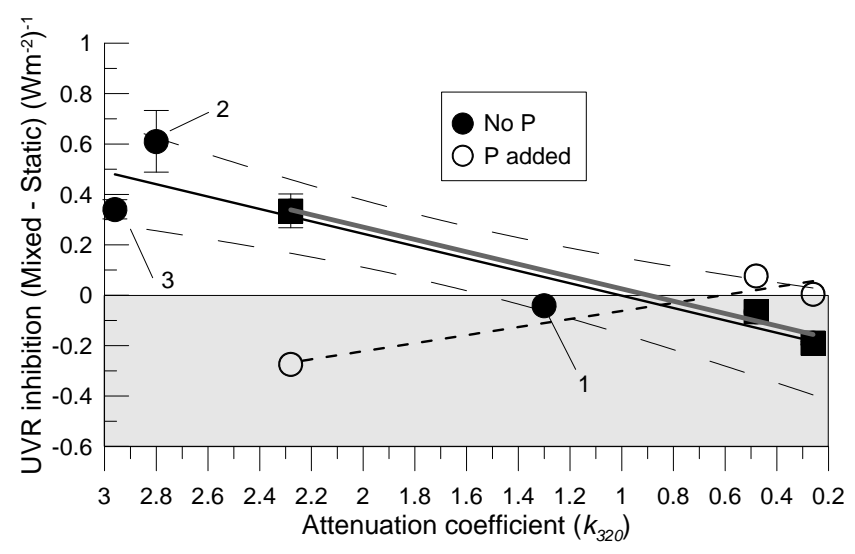

Fig. 7. UVR inhibition of mixed minus static samples, normalized by the mean irradiance received by the cells, as a function of the attenuation coefficient for samples with nutrient addition (white circles) and without (black circles and squares) nutrient addition. The lines represent the fit of linear regression for six lakes (black line); for the three lakes of this study without (gray thick line) or with (dashed line) nutrient addition. The dashed thin lines are the $95 \%$ confidence limits for the fit of six lakes. Additional data calculated from: (1) Köhler et al. (2001), (2) Hiriart-Baer and Smith (2005) and (3) Villafañe et al. (2007).

or having no effect in the clear lakes, but significantly counteracting the negative effects of UVR in the opaque LE.

\section{Discussion}

The main goal of this study was to address the question of how short-term pulses of nutrient inputs, together with vertical mixing and increased UVR fluxes modify the photosynthetic responses of phytoplankton. For this purpose, we performed complex in situ experiments in three high mountain lakes as model ecosystems to evaluate the joint impact of these climate change variables, as this kind of lakes might be considered "sentinels of change" (Catalan et al., 2006; Williamson et al., 2009). The three tested lakes are representative of different areas in terms of their optical characteristics (e.g. Rose et al., 2009). It is important to mention that we did our experiments during the middle ice-free period as it represents a particularly stressful scenario for algae responses due to increasing stratification and higher exposure to solar radiation. In this study, however, we are not addressing the long-term impact, or interactions of these variables, on photoadaptation or changes in species composition, but certainly they are important issues to be considered for future studies.

In a context of global change, it is expected that an increase in temperature would decrease the depth of the epilimnion (Beardall et al., 2009; Raven et al., 2011) while increasing wind speed and duration would enhance mixing. Eventually, persistence of high winds would counteract this effect (depending on the strength of the pycnocline) by increasing the epilimnion depth and also by distributing particles/nutrients transported via the atmosphere (Escudero et al., 2005; Bullejos et al., 2010) and into the water column (i.e. nutrients reaching different depths due to vertical mixing transport). Moreover, an increase in precipitation is predicted over the Northern Hemisphere (IPCC, 2007) therefore, higher inputs of organic matter from water run-off is expected in lakes (Williamson and Rose, 2010). This input would bring more nutrients into the system but will also decrease the penetration of solar radiation (Osburn and Morris, 2003). Due to this, DOM has been considered the "ozone of the underwater world" (Williamson and Rose, 2010) with the implicit view as protector against solar UVR.

An intrinsic factor that conditions the response of phytoplankton to UVR exposure is their previous light history. There are many changes in the cells, such as those in size (Falkowski and Owens, 1980; Garcia-Pichel, 1994), carbon to Chl $a$ ratio (Falkowski and Wirick, 1981; Villafañe et al., 1993), pigment composition or protection mechanisms to cope with UVR (Buma et al., 2009; Van de Poll and Buma, 2009) that allow phytoplankton to acclimate to high or low irradiance. Overall, it is expected that since phytoplankton from opaque lakes receive less solar radiation as compared with those from clear lakes, the former are less acclimated to cope with solar UVR. Surprisingly, relatively few studies clearly addressed this topic: the higher sensitivity of phytoplankton from opaque lakes as compared with clear ones was observed when evaluating UVB-induced DNA damage in several Andean lakes (Villafañe et al., 2004). Recent studies using model simulations (Harrison and Smith, 2011) indicated that phytoplankton from opaque lakes were less resistant as compared with those from clear environments, as the latter have slightly higher photoinhibition in spite of the higher UVR exposure; this resulted in less inhibition per unit energy in clear lakes. Likewise, Ayoub et al. (2012) in doing a transect along the shoreline, showed that the content of mycosporine like amino acids (MAAs) in surface samples increased with decreasing concentration of CDOM in the water, suggesting the photoacclimation to high irradiance in the clear environment.

Vertical mixing and a subsequent increase of UVR due to the formation of a shallower epilimnion, might complicate the protecting view of DOM. Mixing takes cells up and down within the epilimnion and thus decreases the "protecting DOM layer" every time they go towards the surface. In addition, the pulsed supply of nutrients of Saharan dust, which over the last two decades increased almost 2-fold (Bullejos et al., 2010), conditions the physiological responses of phytoplankton already acclimated to different light environments as nutrient status plays a significant role in the observed photosynthetic inhibition (Beardall et al., 2009). Overall, the interaction among these variables might create a new balance between damage/utilization-repair of UVR effects on phytoplankton. In this sense, our results show the following: 


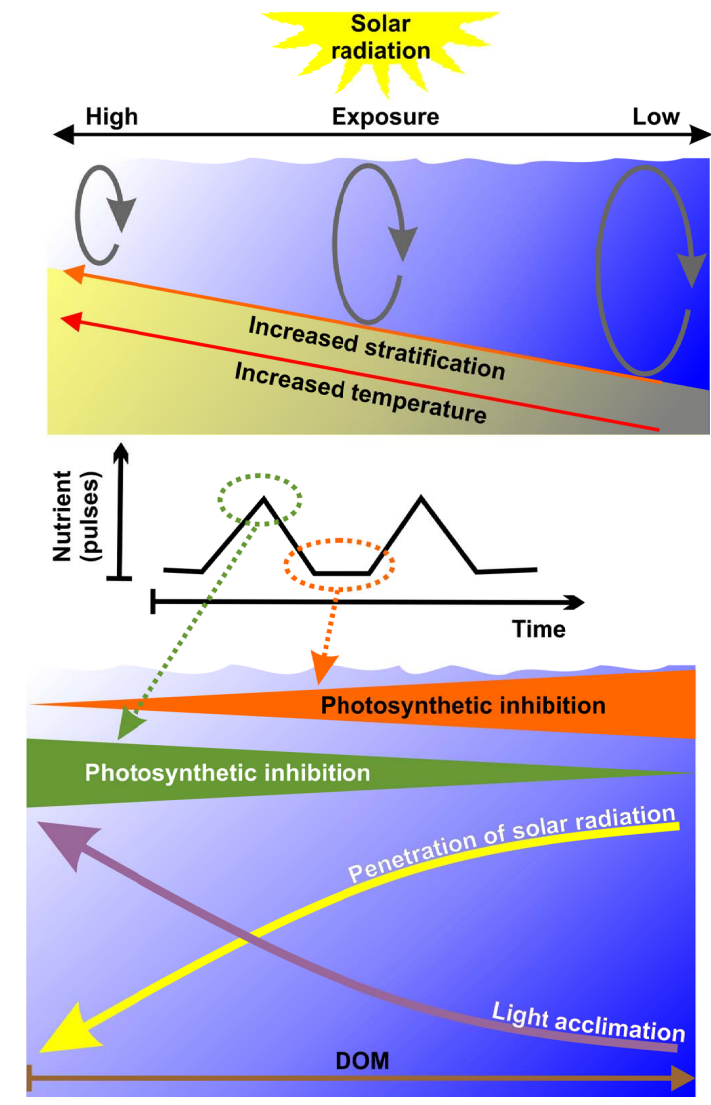

Fig. 8. Conceptual graphical model of photosynthetic inhibition when subjected to interactions among vertical mixing, nutrients and exposure to UVR. The upper panel shows the increased stratification due to enhanced temperatures, from deep mixing (dark blue) towards a shallow epilimnion (light blue), causing more exposure to solar radiation. The frequency of nutrient pulses as a function of time (from Jabalera Cabrerizo, 2012) indicate the timing of our experiment (no pulse - orange) and our simulation of high nutrients during a pulse (green). The lower panel shows the epilimnion under stratified condition, with color gradient indicating changes in water transparency due to DOM. Acclimation to high irradiance results in an inverse relationship with increasing DOM, and photosynthetic inhibition change (estimated as the difference between mixed minus static samples) from clear to opaque lakes, as well as with nutrient input.

under nutrient limitation (mainly of $\mathrm{P}$ ) there is a synergistic effect between vertical mixing and UVR on phytoplankton from opaque lakes, resulting in higher photosynthetic inhibition than if cells received constant mean irradiance within the epilimnion (Figs. 4, 7). The opposite occurs in clear lakes where antagonistic effects are determined and mixing partially counteracted the negative effects of UVR. It has been reported that in clear lakes, with cells acclimated to high irradiance conditions, the impact of UVR due to this fluctuating irradiance is minimum (Fig. 5, Villafañe et al., 2004) as cells, provided they have enough time to acclimate, have different mechanisms to cope with UVR as previously mentioned.
In the case of opaque lakes, however, mixing will result in damage of cells when they are at the surface, and depending on the rates of damage/repair, this could be cumulative causing increased photosynthetic inhibition. A rather similar behavior (in regard to photosynthetic inhibition) was observed in Antarctic phytoplankton under mixing conditions, but that was mostly related to the lack or slow repair due to low temperature (Helbling et al., 1994; Neale et al., 1998). In addition, the input of nutrients (i.e. due to pulses of Saharan dust carried by the winds) reversed these UVR-induced damage effects and clear lakes became more inhibited during mixing, while opaque lakes benefited from the fluctuating irradiance regime. Although UVR impact is also modulated by other intrinsic and extrinsic factors (e.g. species composition, temperature, etc.) our study considered the penetration of solar radiation as a common "driving force" for general acclimation, based on our in situ experimental results as well as data reported from other lakes (Fig. 7).

In summary, and according to our hypothesis, and in contrast to the expected protecting effect of increased allocthonous DOM, we found that imposing a fluctuating irradiance regime (i.e. mimicking the mixing in the upper layer of stratified lakes, due to global warming) promotes UVRinhibition of primary producers in opaque ecosystems, which is reversed after pulses of nutrients; the opposite responses were found in clear lakes. Based on our results, we propose a conceptual model (Fig. 8) where we also included some of the natural forces of climate change variables considered in our experimental design: (i) increased temperature that would isolate the epilimnion from the deeper and colder water column, thus precluding nutrients from below from reaching the photoactive zone (Beardall et al., 2009; Neale et al., 2003); (ii) nutrient pulse loads by wind or by run-off (LópezMerino et al., 2011; Carrillo et al., 2008; Morales-Baquero et al., 2006); (iii) mixing, due to increased wind forcing, which causes cells to be exposed to a fluctuating radiation field that goes from low irradiance (at the base of the epilimnion) to maximal irradiance at the surface.

Since the interaction of these three factors (i.e. nutrient addition, mixing, and UVR) has not been previously examined by simultaneous experimental manipulation, it is obvious that more data need to be procured in order to fully understand these responses by autotrophic organisms, not only in the short-term (as considered in this study) but also in the long-term. These changes in nutrient pulses, together with fluctuating radiation conditions, would differentially affect clear and opaque lakes; hence, and due to their key role in carbon flux, variables such as mixing, UVR and nutrients may act in a synergistic or antagonistic way depending on the previous light acclimation of algae. This would not only affect the photosynthesis and production in lakes but it might also influence the microbial loop and trophic interactions via enhanced EOC (Medina-Sánchez et al., 2006) under fluctuating UVR exposure. 


\section{Supplementary material related to this article is available online at: http://www.biogeosciences.net/10/ 1037/2013/bg-10-1037-2013-supplement.pdf.}

Acknowledgements. This work was supported by Ministerio Español de Medio Ambiente, Rural y Marino (PN2009/067) and Ciencia e Innovación (GLC2008-01127/BOS and CGL201123681), Junta de Andalucía (Excelencia CVI-02598), Agencia Nacional de Promoción Científica y Tecnológica (PICT 2007-1651) and Fundación Playa Unión; GH and CD were supported by the Spanish Government - Formación de Profesorado Universitario Grant. We are indebted to the staff of Sierra Nevada National Park for permission to work and field assistance; R. Gonçalves helped with computer drawings, and J. Rodríguez Huertas, E. Mesa and S. Rosillo helped during field work and with analyses of samples. We thank the valuable comments and suggestions of P. Neale and E. Boss that helped us to improve this manuscript. This is Contribution no. 128 of the Estación de Fotobiología Playa Unión.

Edited by: E. Boss

\section{References}

APHA: Standard methods for the examination of water and wastewater, American Public Health Association, Washington, USA, 1992.

Ayoub, L. M., Hallock, P., Coble, P. G., and Bell, S. S.: MAA-like absorbing substances in Florida Keys phytoplankton vary with distance from shore and CDOM: Implications for coral reefs, J. Exp. Mar. Biol. Ecol., 420, 91-98, 2012.

Barbieri, E. S., Villafañe, V. E., and Helbling, E. W.: Experimental assessment of UV effects upon temperate marine phytoplankton when exposed to variable radiation regimes, Limnol. Oceanogr., 47, 1648-1655, 2002.

Beardall, J., Sobrino, C., and Stojkovic, S.: Interactions between the impacts of ultraviolet radiation, elevated $\mathrm{CO}_{2}$, and nutrient limitation on marine primary producers, Photochem. Photobiol. Sci., 8, 1257-1265, 2009.

Bullejos, F. J., Carrillo, P., Villar-Argaiz, M., and Medina-Sánchez, J. M.: Roles of phosphorus and ultraviolet radiation in the strength of phytoplankton - zooplankton coupling in a Mediterranean high mountain lake, Limnol. Oceanogr., 55, 2549-2562, 2010.

Buma, A. G. J., Boelen, P., and Jeffrey, W. H.: UVR-induced DNA damage in aquatic organisms, in: UV effects in aquatic organisms and ecosystems, edited by: Helbling, E. W. and Zagarese, H. E., Series in Photochemical and Photobiological Sciences, The Royal Society of Chemistry, Cambridge, UK, 291-327, 2003.

Buma, A. G. J., Visser, R. J., Van de Poll, W., Villafañe, V. E., Janknegt, P. J., and Helbling, E. W.: Wavelength-dependent xanthophyll cycle activity in marine microalgae exposed to natural ultraviolet radiation, Eur. J. Phycol., 44, 515-524, 2009.
Carrillo, P., Reche, I., Sánchez-Castillo, P., and Cruz-Pizarro, L.: Direct and indirect effects of grazing on the phytoplankton seasonal succession in an oligotrophic lake, J. Plankton Res., 17, 1363-1379, 1995

Carrillo, P., Reche, I., and Cruz-Pizarro, L.: Intraspecific stoichiometric variability and the ratio of nitrogen to phosphorus resupplied by zooplankton, Freshwat. Biol., 36, 363-374, 1996.

Carrillo, P., Medina-Sánchez, J. M., and Villar-Argaiz, M.: The interaction of phytoplankton and bacteria in a high mountain lake: Importance of the spectral composition of solar radiation, Limnol. Oceanogr., 47, 1294-1306, 2002.

Carrillo, P., Delgado-Molina, J. A., Medina-Sánchez, J. M., Bullejos, F. J., and Villar-Argaiz, M.: Phosphorus inputs unmask negative effects of ultraviolet radiation on algae in a high mountain lake, Global Change Biol., 14, 423-439, 2008.

Catalan, J., Camarero, L., Felip, M., Pla, S., Ventura, M., Buchaca, T., Bartumeus, F., de Mendoza, G., Miró, A., Casamayor, E. O., Medina-Sánchez, J. M., Bacardit, M., Altuna, M., Bartrons, M., and de Quijano, D. D.: High mountain lakes: extreme habitats and witnesses of environmental changes, Limnetica, 25, 551584, 2006

Christensen, M. R., Graham, M. D., Vinebrooke, R. D., Findlay, D. L., Paterson, M. J., and Turner, M. A.: Multiple anthropogenic stressors cause ecological surprises in boreal lakes, Global Change Biol., 12, 2316-2322, 2006.

Crain, C. M., Kroeker, K., and Halpern, B. S.: Interactive and cumulative effects of multiple human stressors in marine systems, Ecol. Lett., 11, 1304-1315, 2008.

Delgado-Molina, J. A.: Efectos interactivos de radiación UV y pulsos de nutrientes sobre la red trófica microbiana: aproximación estructural, estequiométrica y funcional, Ph. D. thesis, Departamento de Ecología, University of Granada, Granada, Spain, 246 pp., 2008.

Delgado-Molina, J. A., Carrillo, P., Medina-Sánchez, J. M., VillarArgaiz, M., and Bullejos, F. J.: Interactive effects of phosphorus loads and ambient ultraviolet radiation on the algal community in a high-mountain lake, J. Plankton Res., 31, 619-634, 2009.

Escudero, M., Castillo, S., Querol, X., Avila, A., Alarcón, M., Viana, M. M., Alastuey, A., Cuevas, E., and Rodríguez, S.: Wet and dry African dust episodes over eastern Spain, J. Geophys. Res., 110, D18S08, doi:10.1029/2004JD004731, 2005.

Evans, C. D., Chapman, P. J., Clark, J. M., Monteith, D. T., and Cresser, M. S.: Alternative explanations for rising dissolved organic carbon export from organic soils, Global Change Biol., 12, 2044-2053, 2006

Falkowski, P. G. and Owens, T. G.: Light-shade adaptation, two strategies in marine phytoplankton, Plant Physiol., 66, 592-595, 1980.

Falkowski, P. G. and Wirick, C. D.: A simulation model of the effects of vertical mixing on primary productivity, Mar. Biol., 65, 69-75, 1981

Figueroa, F. L., Salles, S., Aguilera, J., Jiménez, C., Mercado, J., Viñegla, B., Flores-Moya, A., and Altamirano, M.: Effects of solar radiation on photoinhibition and pigmentation in the red alga Porphyra leucosticta, Mar. Ecol. Prog. Ser., 151, 81-90, 1997.

Findlay, S. E. G.: Increased carbon transport in the Hudson River: Unexpected consequence of nitrogen deposition?, Front. Ecol Environ., 3, 133-137, 2005. 
Folt, C. L., Chen, C. Y., Moore, M. V., and Burnaford, J. L.: Synergism and antagonism among multiple stressors, Limnol. Oceanogr., 44, 864-877, 1999.

Gao, K., Wu, Y., Li, G., Wu, H., Villafañe, V. E., and Helbling, E. W.: Solar UV radiation drives $\mathrm{CO}_{2}$ fixation in marine phytoplankton: A double-edged sword, Plant. Physiol., 144, 54-59, 2007.

Garcia-Pichel, F.: A model for internal self-shading in planktonic organisms and its implications for the usefulness of ultraviolet sunscreens, Limnol. Oceanogr., 39, 1704-1717, 1994.

Häder, D.-P., Helbling, E. W., Williamson, C. E., and Worrest, R. C.: Effects of UV radiation on aquatic ecosystems and interactions with climate change, Photochem. Photobiol. Sci., 10, 242-260, 2011.

Hallegraeff, G. M.: Ocean climate change, phytoplankton community responses, and harmful algal blooms: A formidable predictive challenge, J. Phycol., 46, 220-235, 2010.

Harrison, J. W. and Smith, R. E. H.: The spectral sensitivity of phytoplankton communities to ultraviolet radiation-induced photoinhibition differs among clear and humic temperate lakes, Limnol. Oceanogr., 56, 2115-2126, 2011.

Helbling, E. W., Villafañe, V. E., and Holm-Hansen, O.: Effects of ultraviolet radiation on Antarctic marine phytoplankton photosynthesis with particular attention to the influence of mixing, in: Ultraviolet radiation in Antarctica: Measurements and biological effects, edited by: Weiler, C. S. and Penhale, P. A., American Geophysical Union, Washington, DC, USA, 207-227, 1994.

Helbling, E. W., Gao, K., Gonçalves, R. J., Wu, H., and Villafañe, V. E.: Utilization of solar UV radiation by coastal phytoplankton assemblages off SE China when exposed to fast mixing, Mar. Ecol. Prog. Ser., 259, 59-66, 2003.

Hessen, D. O., Leu, E., Færøvig, P. J., and Petersen, S. F.: Light and spectral properties as determinants of C:N:P-ratios in phytoplankton., Deep-Sea Res. II, 55, 2169-2175, 2008.

Hiriart-Baer, V. P. and Smith, R. E. H.: Models for ultraviolet radiation - dependent photoinhibition of Lake Erie phytoplankton, Limnol. Oceanogr., 49, 202-214, 2004.

Hiriart-Baer, V. P. and Smith, R. E. H.: The effect of ultraviolet radiation on freshwater planktonic primary production: The role of recovery and mixing processes, Limnol. Oceanogr., 50, 13521361, 2005.

Holm-Hansen, O. and Riemann, B.: Chlorophyll a determination: Improvements in methodology, Oikos, 30, 438-447, 1978.

Holm-Hansen, O., Lorenzen, C. J., Holmes, R. W., and Strickland, J. D. H.: Fluorometric determination of chlorophyll, J. Cons. Perm. Int. Explor. Mer., 30, 3-15, 1965.

IPCC: Climate Change 2007: The physical science basis. Contribution of working group I to the fourth assessment report of the Intergovernmental Panel on Climate Change, edited by: Solomon, S., Quin, D., Manning, M., Marquis, M., Averyt, K., Tignor, M. M. B., Miller, L. R., Jr., and Chen, Z., Cambridge University Press, New York, USA, 996 pp., 2007.

Jabalera Cabrerizo, M.: Influencia de la intensidad y frecuencia de pulsos de nutrientes sobre ecosistemas sometidos a estrés por UVR, Master in Ecology, University of Granada, 2012.

Köhler, J., Schmitt, M., Krumbeck, H., Kapfer, M., Litchmann, E., and Neale, P. J.: Effects of UV on carbon assimilation of phytoplankton in a mixed water column, Aquat. Sci., 63, 294-309, 2001.
Lignell, R.: Problems in filtration fractionation of ${ }^{14} \mathrm{C}$ primary productivity samples, Limnol. Oceanogr., 37, 172-178, 1992.

Litchman, E., Neale, P. J., and Banaszak, A. T.: Increased sensitivity to ultraviolet radiation in nitrogen-limited dinoflagellates: Photoprotection and repair, Limnol. Oceanogr., 47, 86-94, 2002.

López-Merino, L., Moreno, A., Leira, M., Sigró, J., GonzálezSampériz, P., Valero-Garcés, B. L., López-Sáez, J. A., Brunet, M., and Aguilar, E.: Two hundred years of environmental change in Picos de Europa National Park inferred from sediments of Lago Enol, northern Iberia, J. Paleolimnol., 46, 453-467, 2011.

Maxwell, K. and Johnson, G. N.: Chlorophyll fluorescence - a practical guide, J. Exp. Bot., 51, 659-668, 2000.

Medina-Sánchez, J. M., Villar-Argaiz, M., Sánchez-Castillo, P., Cruz-Pizarro, L., and Carrillo, P.: Structure changes in a planktonic food web: Biotic and abiotic controls, J. Limnol., 58, 213222, 1999.

Medina-Sánchez, J. M., Villar-Argaiz, M., and Carrillo, P.: Solar radiation - nutrient interaction enhances the resource and predation algal control on bacterioplankton: A short-term experimental study, Limnol. Oceanogr., 51, 913-924, 2006.

Medina-Sánchez, J. M., Carrillo, P., Delgado-Molina, J. A., Bullejos, F. J., and Villar-Argaiz, M.: Patterns of resource limitation of bacteria along a trophic gradient in Mediterranean inland waters, FEMS Microbiol. Ecol., 74, 554-565, 2010.

Morales-Baquero, R., Pulido-Villena, E., and Reche, I.: Atmospheric inputs of phosphorus and nitrogen to the southwest Mediterranean region: Biogeochemical responses of high mountain lakes, Limnol. Oceanogr., 51, 830-837, 2006.

Neale, P. J., Davis, R. F., and Cullen, J. J.: Interactive effects of ozone depletion and vertical mixing on photosynthesis of Antarctic phytoplankton, Nature, 392, 585-589, 1998.

Neale, P. J., Helbling, E. W., and Zagarese, H. E.: Modulation of UVR exposure and effects by vertical mixing and advection, in: UV effects in aquatic organisms and ecosystems, Comprehensive Series in Photochesmitry and Photobiology, 1, edited by: Helbling, E. W. and Zagarese, H. E., The Royal Society of Chemistry, Cambridge, UK, 108-134, 2003.

Osburn, C. L. and Morris, D. P.: Photochemistry of chromophoric dissolved organic matter in natural waters, in: UV effects in aquatic organisms and ecosystems, Comprehensive Series in Photochesmitry and Photobiology, 1, edited by: Helbling, E. W. and Zagarese, H., The Royal Society of Chemistry, Cambridge, UK, 185-217, 2003.

Porra, R. J.: The chequered history of the development and use of simultaneous equations for the accurate determination of chlorophylls $a$ and $b$, Photosynth. Res., 73, 149-156, 2002.

Raven, J. A., Giordano, M., Beardall, J., and Maberly, S. C.: Algal and aquatic plant carbon concentrating mechanisms in relation to environmental change, Photosynth. Res., 109, 281-296, 2011.

Reche, I., Pulido-Villena, E., Conde-Porcuna, J. M., and Carrillo, P.: Photoreactivity of dissolved organic matter from high-mountain lakes of Sierra Nevada, Spain, Arct. Antarct. Alp. Res., 33, 426434, 2001.

Rocha, O. and Duncan, A.: The relationship between cell carbon and cell volume in freshwater algal species used in zooplankton studies, J. Plankton Res., 7, 279-294, 1985.

Rose, K. C., Williamson, C. E., Saros, J. E., Sommaruga, R., and Fischer, J. M.: Differences in UV transparency and thermal structure between alpine and subalpine lakes: implications for organ- 
isms, Photochem. Photobiol. Sci., 8, 1244-1256, 2009.

Shelly, K., Roberts, S., Heraud, P., and Beardall, J.: Interactions between UV-B exposure and phosphorus nutrition. I. Effects on growth, phosphate uptake, and chlorophyll fluorescence, J. Phycol., 41, 1204-1211, 2005.

United Nations Environment Programme, E. E. A. P.: Environmental effects of ozone depletion and its interactions with climate change: progress report, 2011, Photochem. Photobiol. Sci., 11, 13-27, 2012.

Van de Poll, W. H. and Buma, A. G. J.: Does ultraviolet radiation affect the xanthophyll cycle in marine phytoplankton?, Photochem. Photobiol. Sci., 8, 1295-1301, 2009.

Velasco, J. L., Araujo, R., Alvarez, M., Colomer, M., and Baltanás, A.: Aportación al conocimiento limnológico de ocho lagos y lagunas de montaña de Asturias (España). Bol. Real Soc. Esp. Hist. Nat. Biol, 95, 181-191, 1999.

Villafañe, V. E. and Reid, F. M. H.: Métodos de microscopía para la cuantificación del fitoplancton, in: Manual de Métodos Ficológicos, edited by: Alveal, K., Ferrario, M. E., Oliveira, E. C., and Sar, E., Universidad de Concepción, Concepción, Chile, 169-185, 1995.

Villafañe, V. E., Helbling, E. W., and Holm-Hansen, O.: Phytoplankton around Elephant Island, Antarctica. Distribution, biomass and composition, Polar Biol., 13, 183-191, 1993.

Villafañe, V. E., Sundbäck, K., Figueroa, F. L., and Helbling, E. W.: Photosynthesis in the aquatic environment as affected by UVR, in: UV effects in aquatic organisms and ecosystems, edited by: Helbling, E. W. and Zagarese, H. E., Comprehensive Series in Photochemical and Photobiological Sciences, The Royal Society of Chemistry, Cambridge, UK, 357-397, 2003.
Villafañe, V. E., Buma, A. G. J., Boelen, P., and Helbling, E. W.: Solar UVR-induced DNA damage and inhibition of photosynthesis in phytoplankton from Andean lakes of Argentina, Arch. Hydrobiol., 161, 245-266, 2004.

Villafañe, V. E., Gao, K., Li, P., and Helbling, E. W.: Vertical mixing within the epilimnion modulates UVR-induced photoinhibition in tropical freshwater phytoplankton from southern China, Freshwat. Biol., 52, 1260-1270, 2007.

Villar-Argaiz, M., Medina-Sánchez, J. M., Cruz-Pizarro, L., and Carrillo, P.: Inter- and intra-annual variability in the phytoplankton community of a high mountain lake: the influence of external (atmospheric) and internal (recycled) sources of phosphorus, Freshwat. Biol., 46, 1017-1034, 2001.

Villar-Argaiz, M., Bullejos, F. J., Medina-Sánchez, J. M., RamosRodríguez, E., Delgado-Molina, J. A., and Carrillo, P.: Disentangling food quantity and quality effects in zooplankton response to P-enrichment and UV radiation, Limnol. Oceanogr., 57, 235250, 2012.

Williamson, C. E. and Rose, K. C.: When UV meets freshwater, Science, 329, 637-639, 2010.

Williamson, C. E., Saros, J. E., and Schindler, D. W.: Sentinels of change, Science, 323, 887-888, 2009.

Xenopoulos, M. A., Frost, P. C., and Elser, J. J.: Joint effects of UV radiation and phosphorus supply on algal growth rate and elemental composition, Ecology, 83, 423-435, 2002. 